\title{
Sustainable formation of urban development on the example of the primary real estate market in Krakow
}

\author{
Krzysztof Butryn ${ }^{1}$, Elżbieta Jasińska ${ }^{1}$, Oleksandra Kovalyshyn ${ }^{2}$, and Edward Preweda ${ }^{1, *}$ \\ ${ }^{1}$ AGH University of Science and Technology, Poland \\ ${ }^{2}$ Lviv National Agrarian University, Lviv, Ukraine
}

\begin{abstract}
Due to the high demand on the housing market, it may seem that every investment will find buyers' interest and the key is its economic dimension. Meanwhile, in the Krakow real estate market, one can observe the trend of SMART market creation, in which the added value is the quality of life of residents of a given investment, especially in terms of using renewable energy sources and ensuring a well-organized space around the investment. The implementation of intelligent energy networks and the widespread use of renewable energy sources will result in more efficient energy transfer, waste recycling, faster identification of the threat and repair after a possible failure. Using, for example, the resources of the National Fund for Environmental Protection and Water Management, the implementation of ecological solutions is not related to the excessive price of such investments, and guarantees a higher quality of life for new owners. The article presents good practices in the design of housing estates in the city of Krakow. One of such closed settlements is "Osiedle Fi", whose location guarantees good public transport, additionally underground parking places a lot of green areas outside, positively affecting the microclimate of the area. The buildings are made of natural materials and the common parts of the property are illuminated from solar energy. The use of renewable energy sources favors both the environment and reduces the cost of maintaining the property. Rainwater is also used. The next smart housing estate is "Osiedle Ozon". It is a comfortable housing estate with functional land development. Among its main attributes, it is worth mentioning a lot of greenery and naturally diversified terrain. There were used plant species, which have the ability to catch harmful chemicals or dust from soil and air. In this work, a statistical analysis was conducted to compare the prices of housing properties in these two selected settlements to the prices of real estate in the area, indicating statistically insignificant differences in the economic aspect, with significant differences in the quality of life of the potential buyer.
\end{abstract}

\section{Introduction}

In the last twenty years, one can notice a change in the way of approaching the surrounding world, the society's awareness of the surrounding environment has been increased, both in terms of drawing from it and what is returned to it. The rapid development of industry, transport or services has moved to everyday life and, above all, its quality. In the case of Kraków, air quality is the most cited, and the fight against this problem is spreading to many branches of the economy, including the real estate market. The popularity of using renewable energy sources or caring about the natural environment is growing. The issue of renewable energy sources will be key in 2020, under the Directive of the European Parliament and of the Council on the promotion of the use of energy from renewable sources [1] which requires $20 \%$ renewable energy in final energy consumption, as well as a $20 \%$ increase in energy efficiency and a $10 \%$ share of biofuels in the total consumption of transport fuels. The aforementioned elements are part of the smart city idea, which is unavoidable in every country. The largest metropolises in Europe, such as Copenhagen or Oslo, have long been implementing smart city solutions and are constantly striving to improve them, Spain already meets the requirements of the RES Directive [2]. It is the present of highly developed countries in Europe and the future of Poland. Innovative technologies are becoming more and more popular in our country, which make life easier for people, while taking care of the environment and taking full advantage of the values of a given place [3]. Everyone wants to live in a place where they will feel comfortable. Therefore, more and more Polish cities strive to implement the smart city idea to attract residents and promote themselves not only within the country, but also abroad. Kraków is the second largest city in Poland in terms of population. Residential construction is developing dynamically here - from the point of view of the number of dwellings completed, it was the leader among Polish cities [4].

\footnotetext{
* Corresponding author: jasinska@agh.edu.pl
} 


\section{Smart City}

\subsection{Smart City assumptions}

According to the strategic documents of the European Union [5], The main essence of a smart city is clean environment, reduction of carbon dioxide emissions and use of renewable energy sources. By definition, the goal of smart city is to reduce greenhouse gas emissions in 2020 by around $40 \%$ through sustainable and intelligent energy management. According to the idea, all these activities take into account the use of modern technologies. This initiative supports all cities in pioneering tasks of the smart city idea. SMART categories are shown in Figure 1.

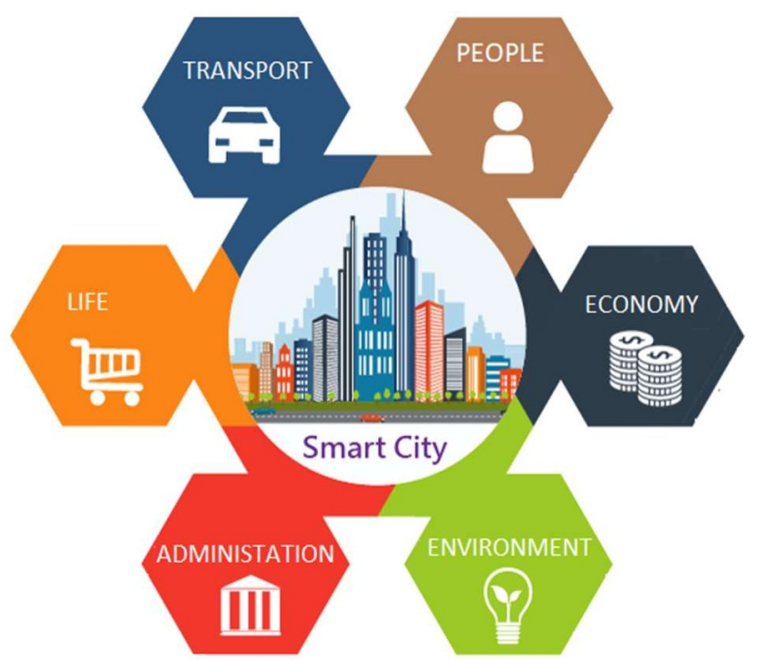

Fig. 1 Categories of SMART City

Each of these categories carries a number of modern solutions that are assessed in the international ranking of SMART cities.

Intelligent transport infrastructure is an important role in a smart and intelligent city. It is also an efficient communication network that allows you to quickly move to other cities. By using advanced technologies, you can optimize traffic, reduce road accidents, improve air quality by reducing emissions. In some places you can increase the capacity of streets or improve travel comfort. Examples of intelligent transport system solutions include e-ticket applications, bus lanes - bus lanes or intelligent intersections. Also, the introduction of motion control sensors is an element of intelligent mobility [6].

An intelligent environment is primarily the use of renewable energy sources. Energy generated from fossil fuels significantly contributes to the emission of greenhouse gases into the environment, and thus climate change. The implementation of intelligent energy networks and the widespread use of renewable energy sources will result in a more efficient transmission of energy [7], waste recycling faster identification of the threat and repair after a breakdown. They are clean, attractive cities, with low levels of pollution and counteracting the devastation of the environment. This is also reflected in the maintenance of smart homes that recover energy by being cheaper to maintain.

- Intelligent administration, by providing information for public inspection. This is an open government rule. The result of such a process is the participation of citizens in making decisions by local authorities. Cooperation with residents will determine their needs. The essence of such a government is an open platform, where public data in a digital format can be reprocessed and analyzed.

- Intelligent economy takes into account modern technologies to optimize the workload and increase their productivity. Enterprising cities that establish cooperation between other cities in the country as well as internationally.

- Intelligent life is evident even from the level of accessibility of health care with the availability of specialist equipment, security of citizens, provision of social assistance and, consequently, obtaining a proper level of living conditions makes the quality of life better. - Intelligent people, or people who want to gain knowledge throughout their lives. They constitute the necessary human capital, which will be the initiator in the intelligent development of the city. They create and use intelligent solutions that are offered to them, they see the need to protect the environment in which they live.

\subsection{Smart City on the real estate market}

Introduction of these ideas to the real estate market is possible for both existing investments and for newly created ones. The main measure will be:

- green roofs with solar cells,

- retention of rainwater,

- solar lamps outside,

- three-layer windows,

- natural building materials,

- double layer of insulation,

- external gym,

- playgrounds, sports fields,

- a lot of greenery and small architecture objects,

- area of premises guaranteeing the comfort of staying.

The most difficult to reach is the last point, i.e. a large area of green areas. Developers very often translate financial profit over the quality of life of residents. As an example, it is worth mentioning a large investment of cheap apartments located at Orlińskiego Street, which attracted prices of 4,000 PLN (at an average price for Kraków PLN 6,000 in 2014), and which is to ultimately be a complex of 3,500 apartments located on an area of 14 hectares of land ( 250 residential premises per 1 hectare of land). It is possible by locating 7-dmio and 15-story buildings, 180 apartments in each. The construction of the investment commenced in 2014, while in 2018 the following problems were publicized [8]:

- lack of a sufficient number of health care institutions, kindergartens, schools - the cost of repair difficult to determine -no smart life

- lack of road infrastructure supporting the estate (restrictions on the exit from the housing estate, 
no bus stops and pedestrian crossings) - planned modernization cost is estimated at PLN 1.17 million - no smart transport

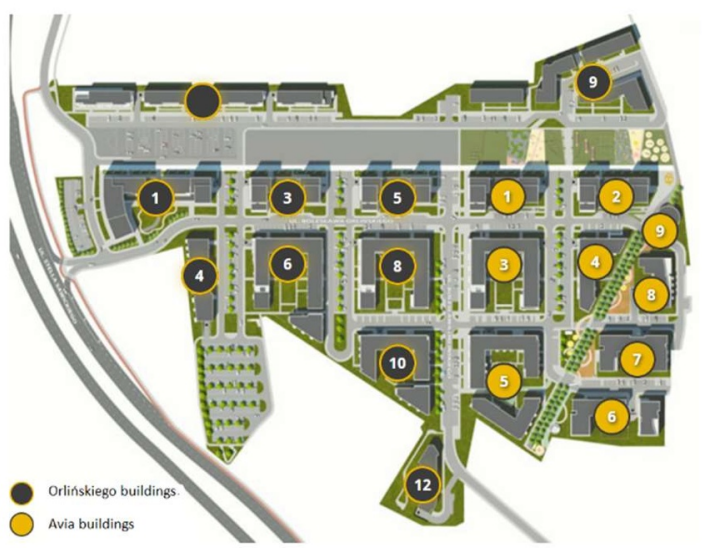

Fig. 2 Plan of AVIA estate and buildings at Orlińskiego street

The given example is a contradiction of the smart idea and for this purpose it has been presented here, however, you can find many examples of implementing SMART principles on the Krakow real estate market. Such settlements have been functioning for many years (created earlier than mentioned above), and many built-up areas in the 1970s require modernization of technology with an emphasis on ecology, to join the SMART group.

Figure 3 presents the project "Fi estate" - a complex of 2.15 hectares, on which there are 483 residential premises - comparing these numbers to the previous example, it is 225 flats per hectare of land. Additionally, environmentfriendly solutions have been used, such as rainwater recovery, use of solar energy or (or above all) a highdensity building materials guaranteeing a higher thermal standard and financial savings in maintaining the premises.

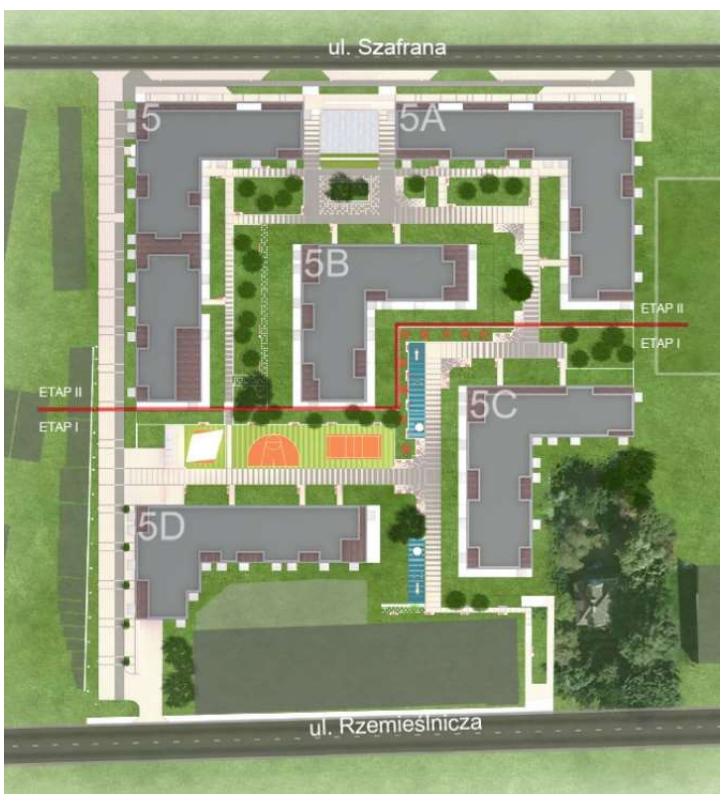

Fig. 3 Plan Fi estate
An absolute leader in caring for the comfort of living is "Ozon Estate", where approx. 400 apartments in eight buildings will be built for approximately 10 ha. The first tenants will enter them at the earliest in mid-2019. The project is being carried out by a company that previously built the Fi housing estate.

\subsection{Activities of city authorities affecting the real estate market}

The main problem of the city is air pollution, which particularly hits the winter season. One of the first initiatives taken to reduce the problem was to co-finance the change in the way of heating flats from coal to electric heating. This solution, of course, concerned buildings from the beginning of the 20th century, located mainly in the city center. In recent years, however, a number of investments have been made to improve the environment, which indirectly affect the real estate market, these are:

- Designation of areas of air corridors where the development is very limited

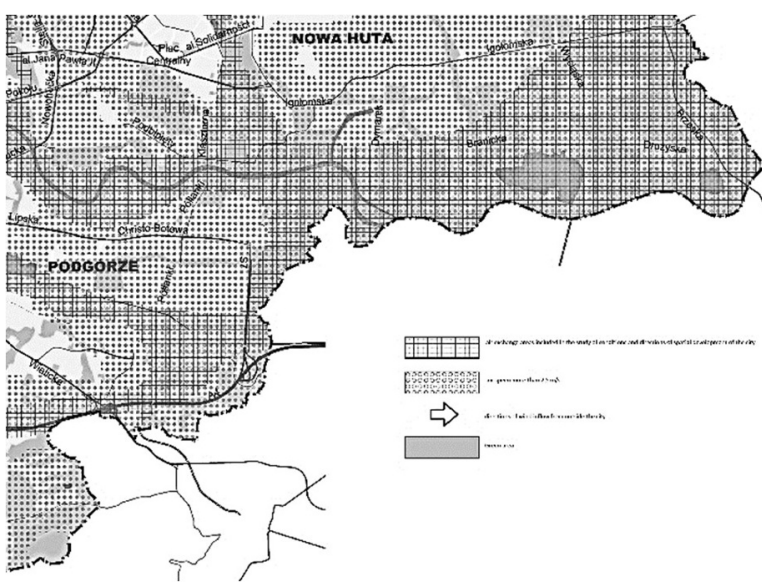

Fig. 4 Air corridors included in the study of conditions and directions of spatial development in the west part of the city

- Designation of areas designated for parks and city greenery

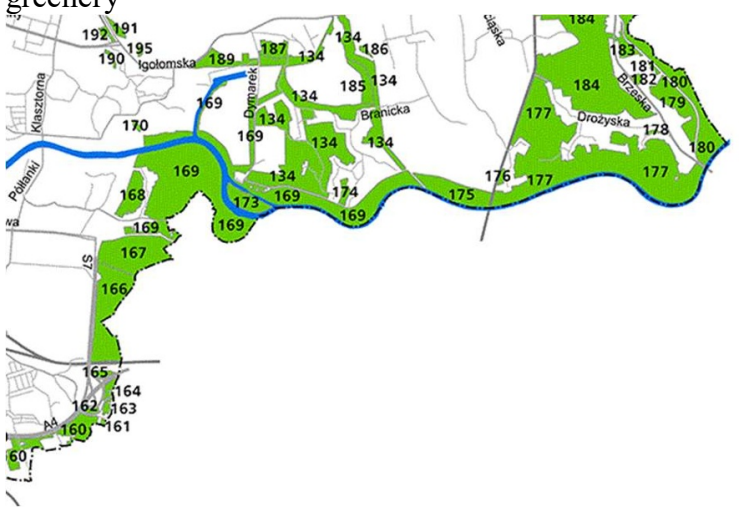

Fig. 5 Areas designated for parks in the study of the conditions and directions of spatial development in the west part of the city

- Development of public transport, expanding car entry restrictions to the city center, introduction of free public 
transport on days when air pollution standards are exceeded.

The real impact on the development market is primarily the blocking of investments in the areas designated for parks (Figure 5) and the restriction of buildings on areas designated for air corridors (Figure 4). Both projects met with the resistance of the local community, and the situation presented in Figure 5 is still in the public consultation phase. The development of public transport infrastructure is much more willingly picked up - this solution raises the prices of real estate in the area. Until, what in Krakow did not enter zones only for electric vehicles, as is the case, for example, in Madrid.

\subsection{Krakow's rating in SMART categories}

As part of the "European Smart Cities" project, a ranking of medium-sized cities that meet smart standards was created, the first place was taken by Luxemburg, while the highest ranked Polish city was Rzeszów. For large cities, there is no such ranking, but they are subjected to such an assessment (Figure 6), and can be compared with others (Figure 7).

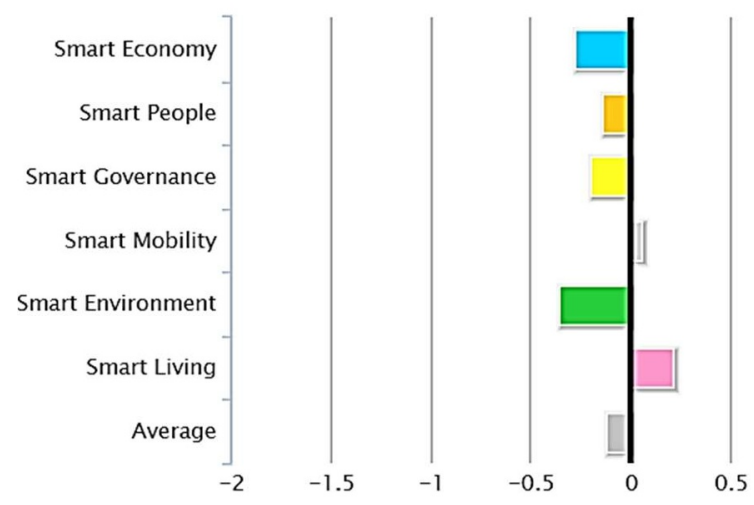

Fig. 6 Scoring the city of Kraków in SMART categories

City profiles: STOCKHOLM (SE), KRAKÓW (PL), GDANSK (PL)

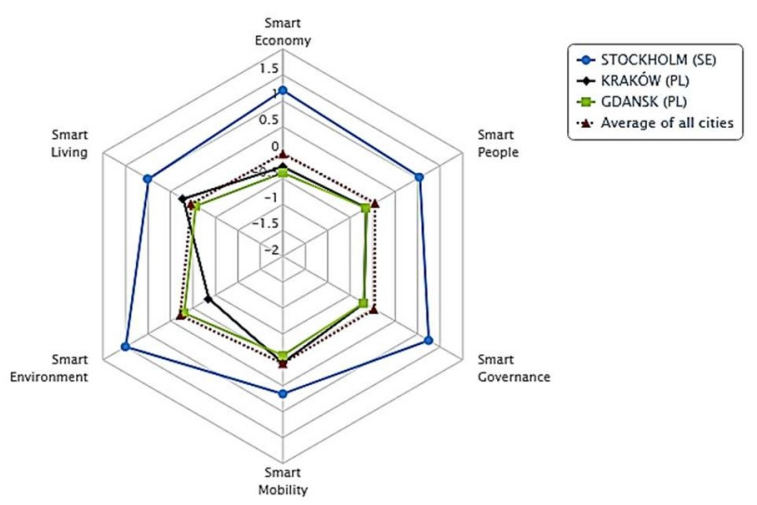

Fig. 7 Comparison of Krakow to Gdańsk and Stockholm

In both charts it can be seen that smart living is the main advantage of the city (above the average determined on the basis of all assessed cities), while smart enviromental - the weakest. A flat in Krakow has its advantages, while the unsolved problem is somehow the air in the city, the lack of green areas or the lack of sufficient use of renewable energy.

\section{Analysis of the real estate market in terms of smart solutions}

\subsection{Potential real estate buyers}

It is worth noting that the smart estate will be directed mainly to people who are looking for real estate for housing needs. Such a person must be aware of the solutions used and be aware that not every housing estate will meet smart conditions, and probably the price of real estate on such a housing estate will not be the lowest on the market. Therefore, the analysis was first analyzed in the structure of potential buyers in terms of the current housing status (Figure 8) [9].

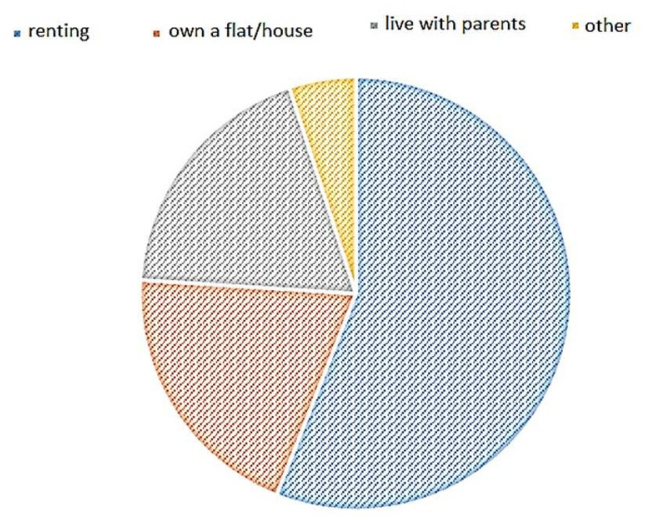

Fig. 8 Structure of potential buyers according to the current housing status

Over $56 \%$ of those who declare a desire to buy their own flat are people who rent a flat. This is good news because it can be assumed that these people already have some experience and opinion about how they want to live or what they want to avoid. Assuming also that the average rent connected with renting an apartment in Krakow is approximately PLN 2 000, this amount may cover an installment of a mortgage loan in the amount of PLN 350-400 hundreds, and this allows the purchase of premises with an area of approximately 60 square meters $[10,11]$.

\subsection{Statistical analysis of the Krakow real estate market}

On the basis of data from the price and value register for the City of Krakow, information about the sale of premises from the primary market was collected, creating a database of nearly 21 thousand transactions concluded in 2017. 
Table 1. Unit price statistics on the primary market

\begin{tabular}{|c|c|c|c|}
\hline $\begin{array}{l}\text { Name of the } \\
\text { district }\end{array}$ & $\begin{array}{l}\text { Amount of } \\
\text { immobilities }\end{array}$ & $\begin{array}{l}\text { The } \\
\text { lowest } \\
\text { unit price } \\
{[\text { PLN/m²] }}\end{array}$ & $\begin{array}{l}\text { The } \\
\text { highest } \\
\text { unit price } \\
{[\text { PLN/m²] }}\end{array}$ \\
\hline Stare Miasto & 64 & 7500 & 13900 \\
\hline Grzegórzki & 2304 & 4990 & 15585 \\
\hline $\begin{array}{l}\text { Prądnik } \\
\text { Czerwony }\end{array}$ & 2287 & 4600 & 10300 \\
\hline Prądnik Biały & 2097 & 4184 & 11263 \\
\hline Krowodrza & 1760 & 4756 & 15000 \\
\hline Bronowice & 1632 & 3246 & 9970 \\
\hline Zwierzyniec & 181 & 13900 & 7750 \\
\hline Dębniki & 650 & 5400 & 16695 \\
\hline $\begin{array}{ll}\text { Lagiewniki } \\
\text { Borek Fałęcki }\end{array}$ & 186 & 4990 & 10290 \\
\hline Swoszowice & 956 & 3141 & 5800 \\
\hline $\begin{array}{l}\text { Podgórze } \\
\text { Duchackie }\end{array}$ & 1124 & 3985 & 10453 \\
\hline $\begin{array}{l}\text { Bieżanów- } \\
\text { Prokocim }\end{array}$ & 1718 & 3667 & 8646 \\
\hline Podgórze & 2231 & 4500 & 12800 \\
\hline Czyżyny & 1792 & 4499 & 8899 \\
\hline Mistrzejowice & 966 & 4500 & 7200 \\
\hline Bieńczyce & 0 & - & - \\
\hline $\begin{array}{l}\text { Wzgórza } \\
\text { Krzesławickie }\end{array}$ & 884 & 3900 & 6500 \\
\hline Nowa Huta & 0 & - & - \\
\hline Kraków & 20832 & 3141 & 16695 \\
\hline
\end{tabular}

Based on this data and on the data obtained directly from the developers, a regression tree scheme was created describing the dependencies present in the database. As a tool for deep analysis, a random forest was selected and the results of the research are presented below.

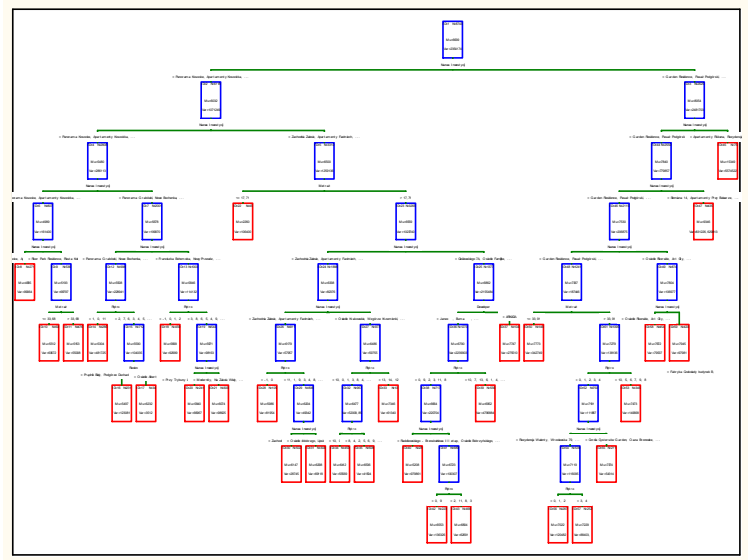

Fig. 9 Decision tree graph for the cessation of features affecting unit property prices
Based on the scheme created in this way, a ranking of the five most important features influencing the real estate price was created (Fig. 10)

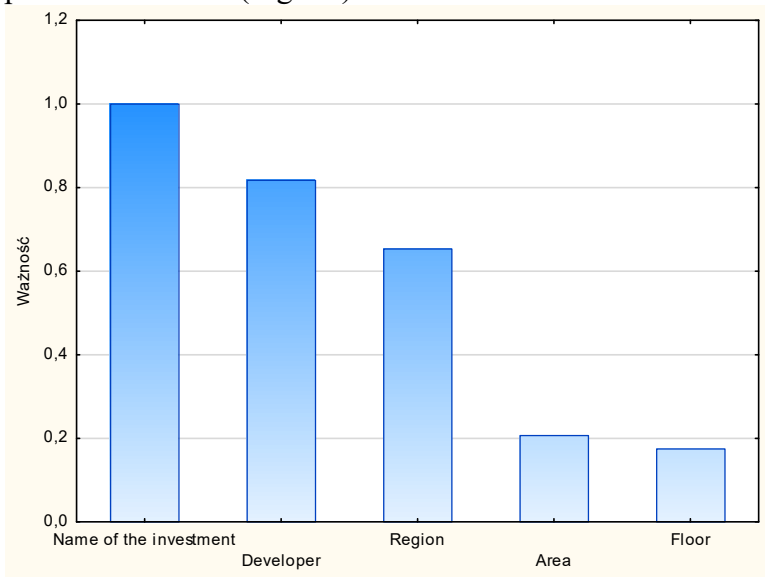

Fig. 10 Ranking of features affecting unit property prices

An additional benefit resulting from the conducted analyzes was the possibility to take into account features that do not appear in classic analyzes, and which often decide on the choice of a specific premises. Among the features that affect the purchase of the premises are:

- exposure / exposure,

-window view,

-green areas,

- location of the flat in the building (corner apartments),

- investment stage,

- building intensity, ongoing next stage of investment,

-communication, technical infrastructure - often planned,

- adjoining rooms (storage rooms, obligatory garages),

- individual discounts.

\subsection{Location of the smart estate in the Krakow realities}

When comparing prices in individual districts of Krakow, it is easy to notice that their minimum and maximum values allow for a wide range of possibilities. Two smart investments, selected in the previous chapter, are located in the district:

- Podgórze (Fi estate) - unit prices range from 4.5 thousand. PLN to almost 13,000 PLN, the average unit price on the Fi estate is 6.3 thous. PLN

- Krzesławickie Hills (Ozon housing estate) - unit prices of the housing estate belong to one of the highest in this district, but it is also worth noting that in that area it is the largest (if not the only) investment.

In terms of the entire city, these are average values. A similar housing estate may be built at the site of the Avia housing estate, which was allowed by undeveloped space. However, due to high demands and lack of social pressure on such a construction, locating such a housing estate in the city center will not be easy. However, you can count on individual blocks, transforming it into a smart idea, as exemplified by the Retmana Tenement, located on Stachowicza Street, or Royal Studio Smart Apartments on November 29 avenue. 
It is much more difficult to find similar solutions in the northern part of Krakow, which is why the authors proposed the location of such a facility, along with the proposal of unit prices of such properties. The presented investment may be located near Wizjonerów st., on the territory of a 3 hectare plot. Looking at Figure 11, you can see changes that have occurred over the past 10 years in the proposed area. First of all, access to the plot was provided - expanding the road lane. In the area, the first multi-family buildings were built, and green areas were also preserved.

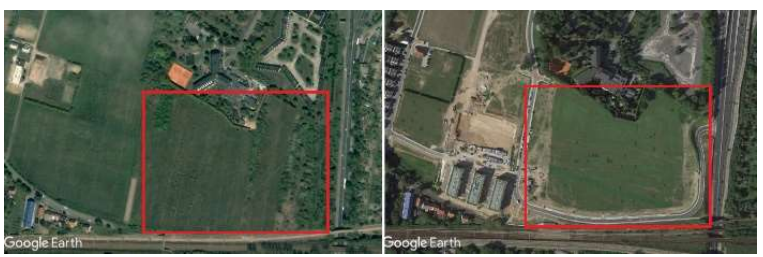

Fig. 11 Aerial photos showing selected locations in 2007 (left side) and 2017 (right side)

The area designated for the development of the new housing estate has been divided into various sectors:

I. I Residential area,

II. A zone of peaceful rest,

III. Sports and recreation zone,

IV. Parking zone.

V. Trade and service zone.

This procedure helps to stop the spatial order and the harmony of the whole estate.

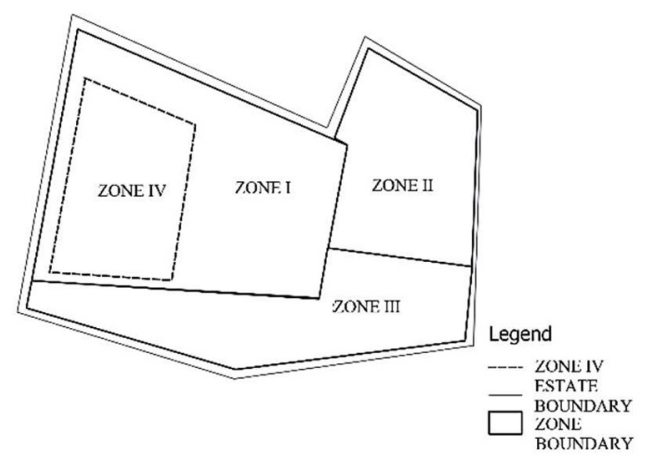

Fig. 12 Graphic division into zones

The residential area I will cover approximately $50 \%$ of the entire housing estate. The whole area was used, which in the local plan was intended for multi-family housing. Due to the fact that the selected area is in the area of air-raids at Balice airport, low construction was designed. For the estate to be consistent, it was erected on four-storey blocks of flats. The layout of the flats will be simple and functional, and the size of apartments of various sizes, so that everyone can tailor it to individual needs. The estate was designed in such a way that the cost of housing maintenance was minimal and environmentally friendly. Natural materials were chosen, in particular white cellular concrete, which is characterized by a low degree of processing and hence, a lot of energy was not used for its processing. Thick walls with a double layer of insulation provide better thermal insulation. This solution will reduce the cost of heating the apartments. Another element is three-layered windows with a thickened wooden frame, which, in addition to improving the insulation, maximally illuminate the interior. In addition to thermal insulation, thick walls and airtight windows dampen the noises created from adjacent railway or public roads. An innovative form of using roof surfaces and increasing biologically active areas are green roofs with solar technology. Plants work as stabilization for photovoltaic panels, increasing their efficiency and lowering the ambient temperature. The green roofs are a place of rest and suppress all noise. In winter, they prevent large thermal losses, while in the summer they protect the building surfaces against excessive heating. Thanks to the solar panels on the roofs, the cost of electricity will be reduced. In an economical and environmentally friendly manner, common parts of residents will be illuminated. Rainwater will be retained in special tanks, which will reduce the cost of watering plants and lawns. This water will also be used to flush toilets.

Zone II will have a lot of high greenery. A lot of trees and ornamental shrubs that can be observed on the bench in peace. This zone was created for morning walks in the park, Sunday rest. Perfect for people who do not have time to drive around Krakow's parks or go to the countryside.

Zone III of sport and recreation is intended for every age group of residents. There will be playgrounds for children. In the neighborhood, external gyms with hydrants are planned, a sports field and tennis courts. There will be smart and safe playgrounds for children. A skatepark was created for some older children. The estate will have a restaurant where everyone can spend time with family and friends. To expand people knowledge, they can spend your free time in a café-library. This zone raises the comfort of living and makes residents want to live and live there.

The parking zone IV will be located underground to save space above ground $[9,12,13]$. Therefore, it was not included on the board. It will also cause that the estate will have peace and security. The area saved was allocated to bicycle paths, walkways and greenery. On the land surface, there will be a place for storing bicycles with the necessary equipment for quick repair. Thanks to this, residents will be able to navigate the city with bicycles efficiently.

Commercial and service shopping arcades have been created in apartment blocks on plates. In it there will be, among others, a pharmacy, hairdresser, delicatessen, bank branch, kindergarten with a nursery, a restaurant and a café-library. The above-mentioned commercial services will make the estate self-sufficient.

It will be a closed estate under constant supervision of security. 24/7 monitoring with a better visibility system at night means that residents will be able to feel safe. The monitoring system will also be powered by solar energy. The space between particular zones will be developed 
with greenery along with benches for rest. In addition to various types of flowers, grasses, the estate will contain special plants that have the ability to catch harmful chemicals from the air and soil. Small solar batteries are also attached to each external lamp to reduce lighting costs. The whole area will include small architectural objects, such as fountains or garden chess.

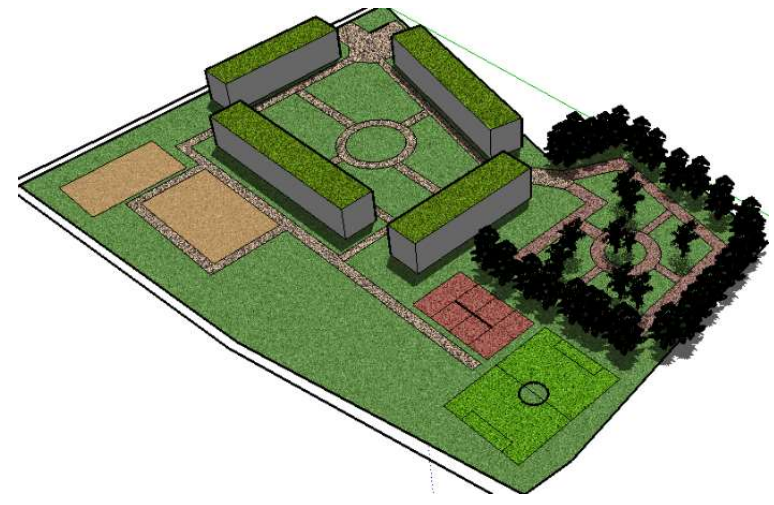

Fig. 13 Visualization of the estate

The whole estate will ultimately have 4 smart city elements. They will be intelligent mobility, intelligent environment, intelligent people and intelligent life. The other two elements refer to the entirety of the city. Analyzing the average unit prices in the area, estimated prices for individual premises were established. The average unit price in the area, which is PLN 6,857.12, is taken into account here. The estate should be in the range of $6,700-7,000$ on the estate PLN $/ \mathrm{m}^{2}$.

Table 2 Unit price statistics on the primary market

\begin{tabular}{|c|c|c|c|}
\hline Lp. & Price & Area & $\begin{array}{c}\text { Price per 1 } \\
\text { sqm }\end{array}$ \\
\hline 1 & 335000 & 48.26 & 6941.57 \\
\hline 2 & 336000 & 45.40 & 7400.88 \\
\hline 3 & 340000 & 49.17 & 6914.79 \\
\hline 4 & 349000 & 52.00 & 6711.54 \\
\hline 5 & 358000 & 52.10 & 6871.40 \\
\hline 6 & 403000 & 60.07 & 6708.84 \\
\hline 7 & 380000 & 56.68 & 6704.30 \\
\hline 8 & 355000 & 52.00 & 6826.92 \\
\hline 9 & 413000 & 63.95 & 6826.92 \\
\hline 10 & 499000 & 71.55 & 6974.14 \\
\hline 11 & 472000 & 69.71 & 6770.91 \\
\hline 12 & 700000 & 96.91 & 7223.20 \\
\hline 13 & 484000 & 71.50 & 6769.23 \\
\hline 14 & 487000 & 70.25 & 6932.38 \\
\hline 15 & 464000 & 69.79 & 6648.52 \\
\hline & & & \\
\hline
\end{tabular}

\section{Conculions}

Krakow is constantly striving to be a smart city. He is the most struggling with a polluted environment. One of the forms of action is the creation of smart housing estates such as the "Fi housing estate" or "Ozon housing estate". Authorities and residents strive for this that the premises of the smart city exist in the city. An example of this is that Krakow wants to develop and strive for the style of the great European metropolises is to organize conferences such as "Smart City-assumptions and perspectives". Comparing old photographs of Krakow's districts you can see how much has already changed. Especially in the communication infrastructure. One could mention many smart city solutions in Krakow, but even more such that can be entered. Therefore, the authorities and residents are constantly striving to introduce new solutions to the ideal city. The main purpose of this work was to locate the housing estate, whose domain will be the smart city idea. After analyzing the available maps and the act on spatial planning with success, you have chosen the right area. As this idea mainly concerns the use of renewable energy sources and environmental protection. the estate was designed like this, to meet these premises. Such solutions should be the future in all cities.

\section{Acknowledgement}

Publication supported by the Polish Ministry of Science and Higher Education as a part of the program of activities disseminating science from the project „Organization of the First International Science Conference - Ecological and Environmental Engineering”, 26-29 June 2018, Kraków.

This work was carried out within the statutory studies of the AGH University of Science and Technology. Faculty of Mining Surveying and Environmental Engineering. Department of Geomatics No. 11.11.150.006.

\section{References}

1. Directives of the European Parliament and of the Council on the promotion of the use of energy from renewable sources (2009/28 / EC)

2. www.ree.es

3. E. Jasińska. Real Estate Due Diligence On the Example of the Polish Market. 14th SGEM GeoConference on Informatics. Geoinformatics and Remote Sensing 2. SGEM2014 Conference Proceedings. June 19-25. 2014. Vol. 2. Bulgaria (2014)

4. E. Jasińska. Land use efficiency on example of the transformation of rural properties. The 10th International Conference Environmental Engineering: selected papers: April 27-28. 2017. Vilnius. Lithuania. (2017).

5. „European Initiative on Smart Cities.” [Online]. Available: https://setis.ec.europa.eu/set-plan- 
implementation/technology-roadmaps/europeaninitiative-smart-cities

6. K. Butryn, E. Preweda, The primary market of parking places against the background of the primary housing market and planning policy on the example of Krakow. The 10th International Conference Environmental Engineering : selected papers : April 27-28, 2017, Vilnius, Lithuania (2017).

7. K. Butryn, E. Preweda, Analysis of the impact of quantitative and qualitative price-setting attributes on a market of real estate intended for the purpose of the transformer stations on the example of Krakow. The 10th International Conference Environmental Engineering : selected papers : April 27-28. 2017. Vilnius. Lithuania. (2017)

8. http://krakow.naszemiasto.pl/artykul/krakowosiedle-avia-staje-sie-problemem-zaplacimyzamiast.4398624.artgal.t.id.tm.html
9. „Popyt i preferencje mieszkaniowe w Krakowie. Badania ankietowe. IV kw. 2016". raport Instytutu Analiz Monitor Rynku Nieruchomości mrn.pl

10. M. Mika. The concept of cadastral tax rates modeling on example of premise real estetes with residential properities in Poland. Acta Sci.Pol. Form. Cir. 16.1: 3-14. (2017)

11. P. Hanus, A. Pęska-Siwik \& R. Szewczyk. Spatial analysis of the accuracy of the cadastral parcel boundaries. Computers and Electronics in Agriculture, 144, p. 9-15. (2018)

12. P. Hanus, P. Benduch \& A. Pęska-Siwik. Problemów z budynkami ciąg dalszy, Cz. 1. Przegląd Geodezyjny 90/2, 24-27. (2018)

13. P. Hanus, P. Benduch \& A. Pęska-Siwik. Problemów z budynkami ciąg dalszy, Cz. 2 .Przegląd Geodezyjny, 90/3, 14-18. (2018). 